\title{
Key factors influencing Local Agenda 21 planning approaches
}

\author{
C. Calabuig ${ }^{1}$, J. Peris ${ }^{1} \&$ G. Ferrero ${ }^{2}$ \\ ${ }^{I}$ Grupo de Estudios en Desarrollo, Cooperación y Ética, \\ Universidad Politécnica de Valencia, Spain \\ ${ }^{2}$ Directorate-General of Development Policy Planning and Evaluation, \\ Secretary of State for Development Cooperation, \\ Ministry of Foreign Affairs and Cooperation, Spain
}

\begin{abstract}
Local Agenda 21 as an instrument for sustainable human development at local level is more than fifteen years old. Its original environmental bias has transformed into a multidimensional conception including social and economic change with strong influences on the political realm. Experience shows that many Local Agenda 21 processes do not obtain the expected outcomes due to many external and internal factors that make human sustainable development difficult to materialise at the local level.

This paper deals with the issue of identifying the endogenous and exogenous variables that determine the development of Local Agenda 21 processes and set the differences among contexts. The emphasis is placed on methodological approaches to Local Agenda 21 planning and management of the process from a governance perspective. These factors can be appropriated for describing the different elements of Local Agenda 21 activities and their relation to long-term development in a city. Planning and management approaches underpinning Local Agenda 21 can thus be assessed in relation to their contribution to human sustainable development.
\end{abstract}

Keywords: Local Agenda 21, strategic planning, sustainable human development, democratic governance, environmental management.

\section{Local Agenda 21 and sustainable human development}

Local Agenda 21 (LA21) is the practical application of the contents of Chapter 28 of Agenda 21, one of the main outcomes of the 1992 Conference on 
Environment and Development. It can be defined as a "participatory, long-term, strategic planning process that addresses priority local sustainable development concerns" (ICLEI, [1]). It is usually developed by municipalities, especially in urban areas.

While the concept of development has evolved in recent decades from paradigms focused almost exclusively on the economic dimension towards others which include ecological and sociopolitical dimensions, such as sustainable development and human development (Froger et al [2], Mebratu [3]), over the years LA21 has also overcome its initial environmentalist bias and common identification with the most visible results of the planning process. According to Bagheri and Hjorth [4], Hardi and Zdan [5] and Meadowcroft et al [6], sustainability is not a static objective but is continuously evolving as our understanding of socio-environmental systems grows. From the different representations of sustainability, the final objective is not so much fair treatment of environmental, economic and social dimensions but to make choices that will serve to strengthen the whole (Kemp et al [7]) over the long term. Beyond action plans, letters of intention on the aims to be pursued (sustainable development) and how to achieve them (strategies, programmes and projects) LA21 should be seen as a dynamic, complex process with an enormous potential for change towards sustainable human development (Learning Community [8]).

This more integral interpretation of the concept of sustainability forms the concept of this present investigation. Our approach is that the objective of LA21 processes and similar initiatives is to progress towards sustainable human development at local level, which according to several studies (among others: [5, 8-18]), can be characterised by the following interrelated dimensions. (1) An integrated approach, with particular focus on environmental protection (integrative perspective, interdisciplinarity, transversality, acceptance of ecological limits, reconsideration of current production and consumption models, adoption of the precautionary principle); (2) development centred on people and their particular environments (empowerment, equity and justice, fight against poverty, welfare of present and future generations, elimination of discrimination, cooperation and security): (3) increased citizen involvement from a sense of responsibility (dialogue, participation, deliberation and consensus, democratic governance, ceding power in the decision-making process, greater prominence for bottom-up processes, generation and increase of existing social capital); (4) fostering co-responsibility (principle of subsidiarity, horizontal and vertical integration, increased decentralisation, greater independence for local government); (5) transparency and accountability (free and accessible information flow, innovative mechanisms for guaranteeing multilevel transparency and accountability, integrity, absence of corruption); (6) encouraging equal cooperation relations (partnerships between local authorities, between local authorities and the community and other stakeholders, commitment at supramunicipal government levels); (7) systematic approach and holistic vision (integration of all the factors affecting the problems and their solution, ecosystem theory applied to the city); (8) fostering a shared strategic vision (attention to short and long term needs and trends, long term but action 
oriented focus); (9) fostering an ongoing collective learning style (learning through experimentation, listening and understanding as basic values, action and reflection as part of a continuous cycle, evaluation with a learning dimension); (10) political will and commitment (involvement and leadership from the local authority, firm commitment to sustainable human development as the guiding focus for municipal policies, consensus among different political parties, dynamic government with greater levels of institutional and social capital); (11) need for process-oriented planning (strategic planning as planning focus, emphasis on intangibles such as knowledge or the nature of social relations, flexibility and adaptation, learning, social trust, process control mechanisms).

Taking as reference the ideas of Vershure and Tuts [19], a measure of the success of a local sustainable human development process such as LA21 will be the extent to which it is related to fundamental change in life styles, particularly those which own, control or consume most of the planets resources.

\section{Lessons learned}

According to several studies [20-25], over fifteen years the number of LA21 processes at world level doesn't reach original expectations and its qualitative impact is limited. The different experiences, especially those in the European context as Europe is the most active region for LA21 (ICLEI [24]), make it possible to identify a series of difficulties and obstacles common to LA21 processes. Below is a selection of said variables that will help to identify the factors influencing LA21 planning approaches. Based on [22, 24, 26, 27], among others, LA21 presents the following difficulties and challenges: non existence of real interdisciplinarity at municipal level, giving rise to sector type adjustments which do not include an integral, interconnected vision of the problems; inadequate organisational structure at local government level; weak participative tradition and limited tradition of collective responsibility; insufficient investment (of economic, material and human resources) in the participative processes as opposed to other dimensions; many LA21 led by elected political representatives and even external agents (as private consultants); compelling and urgent need to resolve everyday problems demanded by citizens and stakeholders which detracts from the ability to reflect, debate, participate and plan; scanty contribution from social networks, especially business organisations; lack of political leadership and consensus in town councils, and short-term vision; decision-making on local issues taken at other levels, with no clear definition of the role of supramunicipal entities; lack of training for technical experts and politicians on sustainability issues; a planning and programming vocation based on an exhaustive diagnostic of the territory, with expert knowledge taking precedence over others (methodologies oriented at developing intangibles such as knowledge, social relations and empowerment are rarely applied); need for flexible implementation and monitoring systems. 


\section{Local Agenda 21 planning dimension}

As shown above, and bearing in mind the very nature of LA21, planning is an inherent part of the process, But despite the fact that there is a wide range of guides for starting up LA21s (internationally for example those promoted by Hewitt [11] and UN-HABITAT \& UNEP [28]), the methodological issues are, in our opinion, one of the aspects to which the scientific community has paid least attention. On possible LA21 models or planning approaches only the analyses by Coenen [29] have been identified who, based on Seip and Van Vliet (1997) (cited in [29]) describes five forms of local planning or LA21 processes focused on communication between the local authority and the different stakeholders.

Bearing in mind current planning trends (Ferrero [30], Friedmann [31], Mayntz [32] and Bagheri et al [4]) we consider that LA21 methodological approaches should take on board aspects such as: changing from normative planning to strategic planning and management, bottom-up rather than top-down approach, the emergence of the local space or the predominance of a holistic rather than a single sector approach. Based on participative or learning approaches (one of whose greatest exponents is D. Korten [33]), Ferrero [30] develops a series of principles and methodological guidelines grouped under the name "development process approach" which guide the design of new planning approaches, methods and instruments most likely to favour sustainable human development processes. From this perspective, we consider that LA21 planning methodologies have a process approach when they promote interventions which: are learning oriented; where design is emergent and bottom-up; where uncertainty is assumed, that is, where flexibility and adaptability predominate; promote participation, the deliberative, concerted search for solutions and democratic decision-making; generate/increase social capital, knowledge, and the building of capabilities; necessarily include the ecological dimension in decision-making.

\section{Factors influencing Local Agenda 21 planning processes}

Based on the lessons learned in LA21 processes and the studies [19, 22, 26, 34 39 ] in addition to our own experience, a series of factors present in LA21 planning and development processes have been identified which are useful for describing the different elements in LA21s and their relationship with long-term sustainable human development processes in municipal areas.

\subsection{Endogenous and exogenous factors}

We have made an initial grouping of endogenous and exogenous variables, where endogenous variables are characteristic of the local environment where LA21 is developed and exogenous variables are external, influencing the local environment and the endogenous variables. These factors are described in summary form in Table 1 and are defined as determining factors in the development of a LA21, acting as differentiating elements in the contexts where the LA21 process is started. 
Table 1: $\quad$ LA21 endogenous and exogenous factors.

\begin{tabular}{|c|c|}
\hline $\begin{array}{l}\text { Origin of the LA21 } \\
\text { initiative }\end{array}$ & $\begin{array}{l}\text { If the process originates with the local government, citizens } \\
\text { groups, supramunicipal public authorities, companies or } \\
\text { universities for example. This origin can have a determining } \\
\text { impact on the process. Particularly significant are the clarity and } \\
\text { realism of the objectives and the honesty of the driver in not } \\
\text { creating false expectations. }\end{array}$ \\
\hline $\begin{array}{l}\text { Municipal administrative } \\
\text { structure and organisation }\end{array}$ & $\begin{array}{l}\text { This refers to both the local authority's capacity to modernise } \\
\text { and the appropriate administrative capacity at local level, } \\
\text { permitting effective devolution of power and providing high } \\
\text { quality public services. }\end{array}$ \\
\hline $\begin{array}{l}\text { Political will, commitment } \\
\text { and leadership }\end{array}$ & $\begin{array}{l}\text { The political adoption of the need to adapt municipal } \\
\text { development to sustainability criteria must extend to all the } \\
\text { municipality's political groups, whether in government or } \\
\text { opposition. It has been shown that political impetus agreed by } \\
\text { consensus among all the parties together with supramunicipal } \\
\text { support is one of the variables that favours the LA21 process. }\end{array}$ \\
\hline $\begin{array}{l}\text { Public awareness and } \\
\text { support }\end{array}$ & $\begin{array}{l}\text { The level of knowledge/ignorance of sustainable human } \\
\text { development in the local corporation and body of experts and } \\
\text { among the public in general exerts an influence. Variables that } \\
\text { favour LA } 21 \text { are: support from associations with presence in the } \\
\text { territory (profit and non-profit) and participation from a wide } \\
\text { number of citizens who join at individual level and the existence } \\
\text { of information and sensitisation strategies. }\end{array}$ \\
\hline $\begin{array}{l}\text { Local democratic } \\
\text { governance }\end{array}$ & $\begin{array}{l}\text { This is understood as the institutional process and framework for } \\
\text { the local environment made up of a system of formal and } \\
\text { informal rules (and the control mechanisms), which establish the } \\
\text { guidelines for interaction between actors in public decision- } \\
\text { making, with said process being governed by the conditions to } \\
\text { be found in democratic systems. }\end{array}$ \\
\hline $\begin{array}{l}\text { Degree of decentralisation, } \\
\text { communication and } \\
\text { coordination with other } \\
\text { public administrations }\end{array}$ & $\begin{array}{l}\text { We are referring to the degree of application of the principle of } \\
\text { subsidiarity (degree of local government independence, power } \\
\text { and competences) and the capacity to influence and be } \\
\text { influenced by supramunicipal levels }\end{array}$ \\
\hline $\begin{array}{l}\text { Resource availability, } \\
\text { mainly economic-financial }\end{array}$ & $\begin{array}{l}\text { Degree of municipal self-sufficiency, dependency on public } \\
\text { funds. }\end{array}$ \\
\hline $\begin{array}{l}\text { Local institutional, } \\
\text { economic, sociopolitical } \\
\text { and ecological context. } \\
\text { Territorial models }\end{array}$ & $\begin{array}{l}\text { Demographic trends, socioeconomic situation, environmental } \\
\text { situation, problems of exclusion, weakness or strength of the } \\
\text { associational movement, presence of human and social capital } \\
\text { (participative tradition in the social structure and the local } \\
\text { corporation's experience in participation and the existence of } \\
\text { spaces and instruments for participation). Also included in this } \\
\text { context variable is the size of the municipal area (no. of } \\
\text { inhabitants and surface area), and the urban/rural nature of the } \\
\text { same, as they determine innumerable aspects including: the } \\
\text { complexity of the socioeconomic, political and environmental } \\
\text { dynamics; ease or otherwise of starting up participative } \\
\text { processes; capacity to obtain resources, etc. }\end{array}$ \\
\hline
\end{tabular}




\section{Table 1: $\quad$ Continued.}

\begin{tabular}{|c|c|}
\hline $\begin{array}{l}\text { Local institutional, } \\
\text { economic, } \\
\text { sociopolitical and } \\
\text { ecological context. } \\
\text { Territorial models }\end{array}$ & $\begin{array}{l}\text { Demographic trends, socioeconomic situation, environmental situation, } \\
\text { problems of exclusion, weakness or strength of the associational } \\
\text { movement, presence of human and social capital (participative tradition } \\
\text { in the social structure and the local corporation's experience in } \\
\text { participation and the existence of spaces and instruments for } \\
\text { participation). Also included in this context variable is the size of the } \\
\text { municipal area (no. of inhabitants and surface area), and the urban/rural } \\
\text { nature of the same, as they determine innumerable aspects including: } \\
\text { the complexity of the socioeconomic, political and environmental } \\
\text { dynamics; ease or otherwise of starting up participative processes; } \\
\text { capacity to obtain resources, etc. }\end{array}$ \\
\hline $\begin{array}{l}\text { Local policies, } \\
\text { legislative and } \\
\text { management } \\
\text { instruments } \\
\text { oriented towards } \\
\text { sustainable human } \\
\text { development }\end{array}$ & $\begin{array}{l}\text { The existence of sustainability policies. In this regard, experiences prior } \\
\text { to LA } 21 \text { (the existence of sustainability-oriented local strategies) } \\
\text { orientation of any existing policies/strategies, etc. Existence/promotion } \\
\text { of participative approaches to decision-making and local politics. } \\
\text { Capacity to apply supramunicipal regulations and legislation to } \\
\text { sustainability issues. Coherent public policies, which integrate } \\
\text { sustainable human development. The existence or opportunity to create a } \\
\text { legal, regulatory framework for decentralised, effective local } \\
\text { development and good local governance. The existence of an } \\
\text { environmental approach and management systems. }\end{array}$ \\
\hline $\begin{array}{l}\text { The region and the } \\
\text { country's } \\
\text { institutional and } \\
\text { economic } \\
\text { environment }\end{array}$ & $\begin{array}{l}\text { Democratic tradition and its degree of development, State capabilities, } \\
\text { governance, vision for the country, public sector integrity and synergy, } \\
\text { trust, levels of corruption, political instability/stability. Stability of the } \\
\text { country's macroeconomic variables, structural reforms applied in the } \\
\text { country, commercial and financial opening-up. It also includes the } \\
\text { degree of existing decentralisation, a variable also typified as an } \\
\text { endogenous factor because it influences the real power of local } \\
\text { governments. }\end{array}$ \\
\hline $\begin{array}{l}\text { Existence of } \\
\text { supramunicipal } \\
\text { policies and } \\
\text { strategies to support } \\
\text { LA21 processes }\end{array}$ & $\begin{array}{l}\text { Where they exist, they favour LA } 21 \text { processes at local scale as they offer } \\
\text { support, largely in the form of economic resources. Specifically, } \\
\text { administrative barriers that hinder the effective introduction of LA } 21 \\
\text { initiatives can be eliminated at state level. }\end{array}$ \\
\hline $\begin{array}{l}\text { Non binding nature } \\
\text { of LA21 }\end{array}$ & $\begin{array}{l}\text { The lack of obligation to comply does not favour the introduction of } \\
\text { LA21, although on the other hand it makes it easier for bottom-up } \\
\text { processes to emerge. }\end{array}$ \\
\hline $\begin{array}{l}\text { Influence of the } \\
\text { development model } \\
\text { based on economic } \\
\text { growth }\end{array}$ & $\begin{array}{l}\text { The influence of this model means that decision-making (in particular } \\
\text { the introduction of policies) prioritises economic growth over other } \\
\text { dimensions of sustainable human development. }\end{array}$ \\
\hline $\begin{array}{l}\text { Competition from } \\
\text { international bodies }\end{array}$ & $\begin{array}{l}\text { This variable refers to the possible influence of international } \\
\text { development cooperation agents and instruments. Those which favour } \\
\text { the introduction of LA } 21 \text { processes and other agents and instruments can } \\
\text { generate a positive or negative impact on local democratic governance } \\
\text { or the achievement of sustainable human development processes. }\end{array}$ \\
\hline
\end{tabular}

\subsection{Factors associated to LA21 planning}

In addition to the above classification, a series of variables linked more directly to LA21 planning, design and implementation process have been identified and are shown in Table 2. The very nature of LA21, rooted in local development processes, means that some of the endogenous factors identified above will also 
be inherent in the LA21 process. This second group of variables attempts to highlight the way the origin, orientation and implementation of the planning and management approaches and methods adopted influence LA21.

Table 2: $\quad$ Factors more directly linked to the LA21 process.

\begin{tabular}{|l|l|}
\hline $\begin{array}{l}\text { Provenance or origin } \\
\text { and approach of LA21 } \\
\text { methodologies }\end{array}$ & $\begin{array}{l}\text { Methodologies with a planning and management } \\
\text { approach oriented to the development process are more } \\
\text { favourable to LA21 processes. This variable includes } \\
\text { both existing approaches and methods and the } \\
\text { characteristics of the LA21 design and implementation } \\
\text { process. }\end{array}$ \\
\hline $\begin{array}{l}\text { Existence of teams, } \\
\text { support experts and } \\
\text { their values, attitudes } \\
\text { and aptitudes. }\end{array}$ & $\begin{array}{l}\text { Under the premise that they must be as interdisciplinary } \\
\text { asternal experts will have an influence. The values of the } \\
\text { staff with a professional or voluntary link to the } \\
\text { organisations involved in LA21 will also have an } \\
\text { influence as they interact with the local environment, } \\
\text { their values being reflected in certain attitudes and } \\
\text { behaviours in their interpersonal and professional } \\
\text { relations. }\end{array}$ \\
\hline $\begin{array}{l}\text { Flexibility and } \\
\text { adaptability }\end{array}$ & $\begin{array}{l}\text { Opportunity and capacity to quickly include } \\
\text { modifications to the preliminary LA21 design as it is } \\
\text { developed. }\end{array}$ \\
\hline $\begin{array}{l}\text { Process of learning in } \\
\text { the intervention and in } \\
\text { organisations }\end{array}$ & $\begin{array}{l}\text { To incorporate experiential learning from LA21 process } \\
\text { into the tacit and explicit knowledge of the organizations } \\
\text { involved. The intervention model incorporates feedback } \\
\text { from these learning processes. }\end{array}$ \\
\hline
\end{tabular}

The above factors (simplification of a much more complex reality) and a planning and management approach oriented towards sustainable human development provide a framework for analysing the way LA21 interacts with development processes. From this representation, which could be further refined, we seek an integrative understanding of the phenomenon to guide improvement of LA21s in terms of quality, implementation capacity and impact on local development processes. Appropriate quality would be achieved by the presence of sustainable human development dimensions in LA21; implementation capacity refers to the real possibility of putting the initiative into practice, through democratic governance systems; a positive impact is understood to be the opportunity for gradual integration in local dynamics of the dimensions of sustainable human development, recognising and valuing specificities and the uniqueness of the local space.

\section{Conclusions}

The main intention of this study has been to offer a framework for analysis to contribute to the description of LA21 processes and external determinants. From 
this perspective it is useful to ask to what extent LA21 planning approaches and methodologies can contribute to sustainable human development.

We consider that in the LA21 processes rather than attaching importance to the formulation of strategies, plans, programmes and projects which may be excellent at a given time, what is truly significant for local sustainable human development is to shape a certain dynamics for interrelation between actors which will institutionalise new conceptions of urban development. This means granting more importance to the intangible aspects of LA21 such as democratic governance, empowerment and the learning of values, skills and knowledge in harmony with sustainability. Clarification of internal and external factors, including those more directly linked to planning aspects, to local development processes in LA21 initiatives is a valuable contribution towards achieving those objectives.

\section{References}

[1] ICLEI, Local Agenda 21 Guidance \& Training Programme, ICLEI \&EU DGXI, 1997.

[2] Froger, G., Méral, P. \& Herimandimby, V., The expansion of participatory governance in the environmental policies of developing countries; the example of Madagascar. International Journal of Sustainable Development, Vol. 7, No 2, 2004.

[3] Mebratu, D., Sustainability and Sustainable Development: historical and conceptual review. Environmental Impact Assessment Review, 18, pp. 493-520, 1998.

[4] Bagheri, A. \& Hjorth, P., Planning for Sustainable Development: a Paradigm Shift Towards a Process-Based Approach. Sustainable Development, 15, pp. 83-96, 2007.

[5] Hardi, P. \& Zdan, T. (coords.) Assessing Sustainable Development. Principles in Practice. International Institute for Sustainable Development: Canada, 1997.

[6] Meadowcroft, J., Farrell, K.N., Spangenberg, J., Developing a framework for sustainability governance in the European Union. International Journal for Sustainable Development, Vol. 8, Nos 1/2, 2005.

[7] Kemp R., Parto, S. \& Gibson, R.B., Governance for sustainable development: moving from theory to practice. International Journal of Sustainable Development, Vol. 8, No 1/2, 2005.

[8] Learning Community, Local Agenda 21 Local \& Participatory Budget. Approaches, methods and instruments for qualified and successful Citizen Participation at the local level, KATE Stuttgart, Stuttgart, 2006.

[9] Evans, B., Joas, M., Sundback, S. \& Theobald, K., "Governing Local Sustainability" Journal of Environmental Planning and Management, Vol 49, No 6, pp. 849-867, 2006.

[10] Graham, J., Amos, B. \& Plumptre, T., Principles for Good Governance in the 21st Century. Policy Brief $\mathrm{N}^{\circ} 15$, Institute on Governance: Canada, 2003. 
[11] Hewitt, N., Guía Europea para la Planificación de las Agendas 21 Locales. Bakeaz: Bilbao, 1998.

[12] Meadowcroft, J., Sustainable Development: A new(ish) idea for a new century? Political Studies, Vol 48, pp. 370-387, 2000.

[13] Meadowcroft, J., Participación y estrategias para el desarrollo sostenible, Revista Instituciones y Desarrollo, 14-15, pp. 123-138, 2003.

[14] Pieterse, E., Participatory Urban Governance, UNCHS (Habitat): Nairobi, 2000.

[15] Roseland, M., Sustainable community development: integrating environmental, economic, and social objectives. Progress in Planning, 54, pp.73-132, 2000.

[16] Peris Blanes. J., Key governance principles underpinning urban sustainable development planning and management. WIT Transactions on Ecology and the Environment. WIT Press, ISSN: 1743-3541, 2008.

[17] UNDP, Governance for sustainable human development. A UNDP policy document, 1997. Online. mirror.undp.org/magnet/policy/summary.htm

[18] Aalborg Charter: Charter of European Cities \& Towns towards Sustainability, 1994. Online. www.aalborgplus10.dk

[19] Verschure, H. \& Tuts, R. Lessons Learnt in Loekx, A.; Shannon, K.; Tuts, R. \& Verschure, K., Urban Trialogues: visions, projects and coproductions. Localizing Agenda 21. UNHABITAT and PGCHS, KU Leuven, 2004.

[20] Comisión Europea, Agenda 21, los primeros cinco años de aplicación de la Agenda 21 en la Comunidad Europea, Comisión Europea DGXI, 1997.

[21] European Commission, Implementing Agenda 21: The EU's Record, July 2002.

[22] Garcia-Sanchez, I.M. \& Prado-Lorenzo, J.M., Determinant Factors in the Degree of Implementation of Local Agenda 21 in the European Union. Sustainable Development, 16, pp. 17-34, 2008.

[23] ICLEI, Local Agenda 21 Survey. UN Department for Policy Coordination and Sustainable Development, 1997.

[24] ICLEI, Second Local Agenda 21 Survey. UN Department for Policy Coordination and Sustainable Development, 2001.

[25] ICLEI - LASALA Project Partners, Local Authorities' Self Assessment of Local Agenda 21 (LASALA). Accelerating Local Sustainability-Evaluating European Local Agenda 21 Processes. Vol I, ICLEI: Freiburg, 2001.

[26] Selman, P., Local Agenda 21: Substance or Spin? Journal of Environmental Planning and Management, 41 (5), pp. 533-553, 1998.

[27] Tuts, R., Habitat's experience in Local Agenda 21 worldwide over the last ten years: approaches and lessons learned UNEP. Industry and Environment January - June, pp. 12-17, 2000.

[28] UN-HABITAT \& UNEP, The SCP Process Activities. The SCP Source Book Series. UN-HABITAT and UNEP: Nairobi, 2004.

[29] Coenen, F.H.J.M., Explaining the potential role of LA-21 processes as a participatory planning reform. General Conference of the European Consortium for Political Research, 2001. 
[30] Ferrero, G., Apoyando los procesos de desarrollo. Enfoques y métodos para una ayuda inclusiva. Working Paper No 17. Fundación Carolina: Madrid, 2008.

[31] Friedmann, J., Globalization and the emerging culture of planning. Progress in Planning, 64, pp. 183-234, 2005.

[32] Mayntz, R., Nuevos desafíos de la teoría del governance. Revista Instituciones y Desarrollo, Vol 7, pp. 35-51, 2000.

[33] Korten, D., Community Organization and Rural Development: A Learning Process Approach. Public Administration Review, 40(5), pp. 480-511, 1980.

[34] Doak, J., Local Agenda 21 and Planning Practice: Structural Transformation or Window Dressing? Centre of Planning Studies, The University of Reading: Reading, 2000.

[35] Peris, J., Acebillo, M. y Calabuig, C. La Agenda 21 Local como instrumento para la gobernanza democrática local. Fundación Carolina, 2008 Online www.fundacioncarolina.es/FundacionCarolina/mwcealci/ cealci/publicaciones/avances/

[36] Gercheva, D., Local sustainable development planning. Manual for a local sustainable development strategy formulation. UNDP, 2003.

[37] Perero, E. (Coord.), Mecanismos de participación ciudadana en los procesos 21. Working Group No 18. Proc. of the VII Congreso Nacional de Medio Ambiente-CONAMA, 2004. Online. www.conama.org/cvii

[38] Plass, A. \& Giralda, A. (coords.), Retos y dificultades en la implantación de las Agendas 21. Proc. of the VI Congreso Nacional de Medio AmbienteCONAMA, 2002. Online. www.conama.es/viconama

[39] Mittler, D., Hijacking Sustainability? Planners and the promise and failure of Local Agenda 21, in Layard, A., Davoudi, S. \& Batty, S. (eds) Planning for a Sustainable Future, Spon Press: London, pp. 53-60, 2001. 